\title{
The Hindu Right and the Politics of Censorship: Three Case Studies of Policing Hindi Cinema (1992-2002)
}

In the 1990s Hindi cinema was firmly entrenched in the contentious sphere of the political. India's Censor Board of Film Certification (or the Censor Board as referred to henceforth), historically considered a primary regulatory mechanism of Hindi cinema and the custodian of public morality by both the citizenry and the State, found itself at the centre of a

maelstrom of moral panics, escalating Hindu right-wing ${ }^{1}$ protest politics, primarily under the aegis of the Bharatiya Janata Party (BJP) and the extremist right-wing party the Shiv Sena, and repeated State interventions. I argue that the 1990s was marked by a gradual alignment of the right-wing nationalist agenda with the historically existing regulatory concerns of the State over the deleterious "effects" of cinema on vulnerable audiences resulting in an unprecedented "censor-wave" (Brinda Bose xxxix). Exemplifying this temporal alignment, each of the three case studies discussed here, including Khalnayak [The Villain (1993)], Bombay (1995) and War and Peace (2002), represents the censorship of a 'sensitive' issue for the Indian State -- sex, religion and national security -- in a prevailing climate of reactionary right-wing politics, anxieties over cultural invasion by globalising forces and unstable coalition governments. It is my contention that censorship as a selective process was an intrinsic principle of Hindu nationalist discourse predicated on a series of exclusions in terms of religion, gender, class, caste that led to the narrow remapping of the national imaginary resulting in the "miniaturisation" of the nation (Sen 46).

The first case study, of Khalnayak, reveals how female sexuality was considered a threat to traditional Indian culture and Indian womanhood by the patriarchal alliance of the State, Hindu nationalist discourse and the viewing public, resulting in moral panics and the demand for stringent obscenity regulations. The protracted censorship controversy 
surrounding Bombay, the second case study, foregrounds the State's anxieties about the cinematic medium engendering Hindu-Muslim communal tensions prompting pre-emptive measures, the extra-constitutional power of Bal Thackeray, the leader of the Shiv Sena, and the direct involvement of the police as censor and arbiter. The third case study, of the documentary War and Peace, exemplifies the overlapping power relations between the Hindu Right and the BJP-led State. It represents the nadir of partisan political interventions under the pretext of safeguarding law and order and the attempted stifling of pluralistic voices in a shrinking public sphere.

Through these three vignettes of landmark censorship controversies, "which reveal how deeply political the whole exercise has become in post-colonial India" (Pendakur, Indian Popular Cinema 79), I attempt to map the field of power relations that existed among the Censor Board and the State, the Hindu Right, the viewing public and various interest groups at a historical conjuncture and to locate various competing yet hierarchical, shifting and diffused sites of political pressure and influence in the public sphere. As Lee Grieveson suggests, such "a struggle over culture and cultural space is, indeed, virtually a defining feature of democratic societies, which almost inevitably involve a complex negotiation between public authority and the dissemination of facts, ideas, and representations in public" ("Policing Cinema" 13). In order to contextualise the persistent regulatory concerns of the state apparatus over "obscene, indecent and/or immoral" cinematic material a brief overview of the 'media-effects' based logic prompting direct State interventions, regulation and the State-instituted codes of censorship is required.

\section{“Why Is Film Censorship Necessary?” (“Annual Report of 1998” 1)}

According to Monika Mehta, “...censorship has been a key point of contact between the post-colonial Indian state, the Bombay film industry, and the Indian citizenry" (170). It is 
interesting to note from a historical survey of cinema and censorship the astonishing fact that at no stage has there been any concerted action for the abolition of censorship per se, despite the film industry's prolonged resentment of the Censor Board's discriminatory policies and practices. A cursory look at the history of Indian cinema reveals a continuous and unequal battle between the Censors and the Hindi film industry. In fact "fear of the censor has caused producers to exercise a strict and much more insidious form of self-imposed censorship," (Vasudev 204) notably through the use of visual metaphor to suggest coupling and sexual intimacy and the absence of the on-screen kiss theorised by Madhava Prasad in his seminal work, Ideology of the Hindi Film: A Historical Construction as symbolic of the "prohibition of the private" which Prasad contends "may well reveal some dirty secrets of the state" (92). He elucidates that,

...the prohibition of kissing is a symptomatic cultural protocol whose origins lie in the need to prevent the dissolution of pre-capitalist patriarchal enclaves, to rein in the forces of democratic transformation. It is not the transparent expression of a preexisting cultural predilection but a 'meaningless' prohibition that regulates the public circulation of images as an obligation of the contract between new and traditional elites. Its tangible result in cinema (which has been the central national cultural institution because mass illiteracy poses obstacles to literature playing a similar role) is a blocking of the representation of the private. (Prasad 100)

For Sheila J. Nayar, popular Hindi cinema's proclivity for "happy endings" suggests "these resolutions are to some degree shaped by censorship codes and are therefore taken by some analysts to be a metaphoric if not blatantly pro-state product of government intervention..." (13-23).

The necessity for some form of manifest, state-sponsored censorship stems from a deeprooted belief by the ruling class/elite that a powerful medium such as cinema should be 
controlled/filtered for the consumption of the "public," a euphemism for lumpen, volatile masses who must be protected from being "exposed to psychologically damaging matter" (“Annual Report of 1998” 1). According to the Censor Board, one of the reasons for justifying the state control of cinema is that "while the media...is free, regarding films it is considered necessary in the general interest to examine the product before it goes out to the public because it is an audio visual medium whose impact is far stronger than that of the printed word” (“Annual Report of 1998” 1). These dubious assumptions about the nature of audiences, audience reception and the necessity for film censorship are given credence by the following Supreme Court verdict ${ }^{2}$ stated in all Censor Board Annual Reports:

Film censorship becomes necessary because a movie motivates thought and action and assures a high degree of attention and retention....It can, therefore be said that the movie has unique capacity to disturb and arouse feelings. It has as much potential for evil as it has for good. It has an equal potential to instil or cultivate violent or good behaviour. With these qualities and since it caters for mass audience who are generally not selective about what they watch, the movie cannot be equated with other modes of communication. It cannot be allowed to function in a free market place as does the newspapers or magazines. Censorship by prior restraint is, therefore, not only desirable but also necessary. (“Annual Report of 1998” 1)

The Supreme Court verdict is based on the oft-cited and problematic assumption that moving images have a direct, causal and quantifiable impact on 'passive' audiences. It adopts the "hypodermic needle model approach," the pit-falls of which are well documented in media studies. Significantly, there were, and continue to be, striking similarities between the rhetoric of moral and regulatory anxieties about the "effect" of the cinematic medium expressed in 1990s India and in early twentieth century America. ${ }^{3}$ The anachronistic notion of the "mimetic" effect of the medium on masses or "crowds" (Grieveson "Cinema Studies") 
holds tremendous sway, one that continues to be invested in by the State, the elite and the citizenry, informing censorship codes and the differential regulatory mechanisms for the press and the cinema in India.

\section{Legal Provisions for Censorship of Hindi Cinema}

Manifest censorship is possible by the State through legal provisions that sanction direct interventions and regulation of cinema. These codes are firstly, The Cinematograph Act of 1952 which repealed the 1918 Cinematograph Act; secondly, the 1994 Revision of the 1952 Censor Board guidelines ("New Instructions For Film Censorship,") and lastly, the Indecent Representation of Women (Prohibition) Act, 1986, "the single most important landmark in the history of censorship in modern India" (Brinda Bose xxx, 101-106). ${ }^{4}$ These legal provisions emanate from Article 19, Clause 1 (a) of the Constitution, that guarantees to every citizen of India the Right to Freedom of Speech and Expression ("Film Censorship: What Everyone Should Know” 2). However, Clause 2 of Article 19 modifies this freedom to "reasonable restriction" and reads as follows:

...law imposes reasonable restrictions on the exercise of the right conferred...in the interest of the sovereignty and integrity of India, the security of the state, friendly relations with foreign states, public order, decency or morality or in relation to contempt of court, defamation or incitement to an offence. (“Annual Report of 1998” 1)

This is the constitutional provision adopted by the Cinematograph Act of 1952, as amended up to 1983. The organisational structure of the Censor Board of India and the guidelines for censorship are based on the provisions of this Act and the Cinematograph (Certification) Rules 1983. Through this Act the state exercises its stranglehold on filmmaking by making it obligatory for every producer to obtain the censor certificate of clearance before the release of the film for public exhibition. Failure to do so attracts 
penalties ranging from fines to imprisonment, requiring even the censorship of pre-released film posters by the Censors ("Film Censorship: What Everyone Should Know" 12-15).

\section{The Cultural Policy of the BJP}

From the early 1990s there were persistent public anxieties over the moral, social, and political stability that historians have characterized as a "search for order" (Grieveson "Policing Cinema" 13) in the face of forces of globalization, coalition politics, economic liberalization and the arrival of foreign and privately-owned satellite and cable television. In this period of flux, the insecurities of a nation were exploited to serve a nationalist agenda of the Hindu Right. I shall now provide a synoptic view of the politics of the Hindu Right and its manifesto on media, cinema and society in order to contextualise the volatile milieu in which the censorship mechanism operated.

The Hindu Right emerged as a powerful force in a relatively short period of time that saw the meteoric rise of its political arm, the BJP, from a fringe party with only two parliamentary seats in 1984 to electoral power in 1999, with 182 seats. It was the single largest party that led a right-wing coalition government called the National Democratic Alliance (NDA) heralding the beginning of a five-year span of Hindu nationalist politics until its defeat in the May 2004 General Elections (Sen 50). The ideology of the Hindu Right is based on a revivalist and neo-traditionalist version of Hinduism known as Hindutva ${ }^{5}$ It created a repressive regime based on propaganda, rhetoric of anti-Muslim "hate speech" (Kapur WS15-WS30) and confrontational politics that disavowed the capacious, heterodox nature of Hinduism, undermining the nation's secular and democratic credentials (Sen 45$50)$.

Ravi Vasudevan makes the following observation that articulates symbiotic representational links between the Hindutva brand of divisive politics and Indian cinema: 
...the Hindutva movement has ideologically and physically targeted various minority formations, primarily the Muslims, but in the recent past Indian Christians as well...In complicated ways, Indian cinema has both played on and contributed to these political formations. (120)

According to Sohini Ghosh, "the Hindu Right was quicker (than other political factions) to sense the subversive potential of popular cinema" ("Troubled Existence" 238); an astute observation confirmed by the BJP electoral manifesto of 1998 outlined its policy on Media, Cinema, Arts:

The BJP believes that, a healthy polity and democracy cannot survive without the support of an extra-political moral order which the democratic political order cannot itself impose on its citizens...Fortunately, at the family and social levels, the age-old dharma, ${ }^{6}$ which is distinct from religious practice, acts as an extra-political normative moral order. But the normative moral order or dharma needs to be protected and preserved as it is already under pressure. With this end in view, the BJP will strive for a national consensus with the involvement of all sections of the Indian society for a voluntary moral standard for the media, for the media plays a very important role both in fostering and prejudicing such a moral order. (www.bjp.org/manifes/chap17.htm)

Specifically on cinema the 1998 manifesto stated:

Popular cinema has played an important role in promoting social harmony and nationalism, apart from providing inexpensive entertainment to the masses. However, in recent years, popular cinema, increasingly funded by the underworld ${ }^{7}$, has had a negative impact on society, especially on impressionable young minds. Sex and violence on the screen is beginning to gnaw at the moorings of our cultural ethos. The BJP is 
committed to checking this abuse of popular cinema. (www.bjp.org/manifes/chap17)

[added emphases]

I argue that in pursuit of the aforementioned voluntary moral standard for the media and the protection of dharma, the Hindu Right, initially under the auspices of the BJP Film Cell, acted both as an instigator and a catalyst for moral panics that served its reactionary cultural agenda of homogenisation dubbed "national consensus."

The exponential rise of the Hindu Right through the 1990s coincided with numerous attempts at cultural censorship of speech, paintings, books, magazines, advertisements, Hindi films and television soaps. ${ }^{8}$ Television played a crucial role in articulating and circulating contested nationalist imaginations on Indian/Hindu culture, the nation and national identity with the establishment of foreign and private channels such as Rupert Murdoch's STAR TV post-1991 that ended decades of monopoly by the State channel, Doordarshan. Significantly, the Hindu Right had appropriated the popularity of two serials based on the Hindu epics, Ramayana and Mahabharata, televised on Doordarshan in the late '80s, to mobilise its brand of nationalism for electoral gains as demonstrated in the seminal work by Arvind Rajagopal. ${ }^{9}$ In Shanti Kumar's opinion, it was "disturbing (in)... the way the BJP and its allies willingly perpetuate(d) this fallacious view of religion and nationalism in their electoral politics" (37).

As Kumar observes, “...the medium of television has emerged as the new battleground for competing visions of nationalism, transnationalism, and translocalism in postcolonial India" (156). He argues, through his close readings of "transient transgression(s)" (182) on STAR TV's now-defunct Nikki Tonight chat show on which Mahatma Gandhi was referred to as "a bastard bania" ${ }^{10}$ by a gay rights activist in May 1995, that television "is the preeminent site for the expenditure of cultural excess (often transgressive) in India today... provid(ing) an illuminating framework for the study of 
unimaginable communities of nationalism in the dynamic flows of electronic capitalism" (186). The Miss World pageant held in November 1996 in the southern Indian city of Bangalore provided a pretext for the BJP "to fuel the cultural anxieties of nationalism" in its aggressive opposition to it that "had the potential to appropriate all other forms of cultural criticism...in the national community" (Kumar 142). The Hinduvta concept of Indian/Hindu femininity and its critique of 'decadent' Western/‘foreign' notions of female sexuality dominated the hotly-contested cultural debates that "became the symbolic condensation of what India had to fear most from the government's policies of economic liberalization and the growing power of transnational corporations $(145) .{ }^{11}$

Thus there was a growing tendency towards cultural protectionism as a chorus of voices repeatedly raised objections to 'obscenity and violence' on foreign media channels. A discursive rhetoric of public ${ }^{12}$ anxiety that repeatedly targeted women and children primarily focused on measures to control the corrupting influence of transnational media (Oza 10671095). 1990s television was crucial for understanding how various 'publics' along religious lines were mobilized in the name of 'Indian' culture and the measures taken to control transgressive moments on television reinforced film and state-sponsored censorship.

\section{Case Study: Khalnayak (1993)}

In 1993, debates over 'obscenity and vulgarity' gathered momentum with the release of the controversial film Khalnayak featuring the provocative song picturisation of the popular Rajasthani folk song Choli ke peechey kya hai (What's beneath the blouse?) which self-styled moralists believed plunged the nation into the abyss of moral turpitude. The choli controversy debated whether or not the song, based on innuendo and double entendre, was vulgar and obscene and exemplified the rhetoric adopted by the BJP and its affiliates to instigate and mobilise public outrage, moral panics and litigations over sexually explicit and/or violent films. The concern over sexual explicitness reached a fever pitch as the song 
articulated a major representational shift concerning women that blurred the distinction between the 'bad' vamp (Westernised, sexy and promiscuous) and the 'good' heroine (chaste and virtuous) (Ghosh 'The Troubled Existence” 238-9). This film best illustrates how the three major players in this drama - the censor, the filmmaker and the public - determined the fortune of a film.

The Hindu Right's attack against the song was led by the Shiv Sena in Bombay and the students' wing of the BJP in Delhi. R. P Chugh, an advocate and a BJP supporter, filed a petition in the Delhi High Court asking for the deletion of the film song and a ban on audiocassette sales (Ghosh Feminists Engage With Censorship). The petition, in alleging that the song was ‘vulgar, against public morality and decency' drew upon three specific assumptions typical of any patriarchal discourse on sexuality in India: firstly that sexuality is obscene; secondly, that any reference to sex amounts to denigrating women, and thirdly, that the entry of sexuality in public space disturbs social equilibrium (Mehta 173). After dismissal of the case by the trial court, the petitioners went to the High Court with the appeal that left unchallenged the court's decision would be an incentive to depicting increasing vulgarity on screen, which in turn, would lead to increasing sexual harassment. The High Court dismissed the petition in a fourteen-page order on the ground that (a) film viewing was a matter of choice with no coercion involved; (b) that it was 'sheer imagination' that the song would lead to 'eve-teasing, ${ }^{13}$ and (c) the alleged vulgarity was acceptable to society in keeping with 'latest developments' in the film world (Ghosh "Feminists Engage With Censorship").

The choli song sequence occurs twice in the film. As Ghosh points out, the allegedly 'indecent' sequence is sung and performed by two women masquerading as prostitutes performing in a gangster's den. This sequence gestures towards the subversive as it creates a space for the articulation of female sexuality momentarily in an otherwise male-dominated conservative film (Ghosh "The Troubled Existence" 257). The second sequence, with 
identical lyrics and music, is sung and performed by men, culminating in the intimidation and physical assault of the heroine by the male protagonist. Ironically, both the petition and the protesters chose to ignore this sequence whilst demanding "censorship of not the sequence that actually depicted violence against women but one that represented sexual agency on their part” (Ghosh "The Troubled Existence” 239).

Khalnayak was ultimately granted a UA certificate ${ }^{14}$ subject to seven cuts, three of which pertained to the "first picturisation of the song" in Reel No. Six and read as follows:

- Delete the words "What is beneath the blouse" from the song sequence

- Delete the visuals of Ganga pointing at her breast in the song...

- Delete the close visuals of pelvic jerks of dancing girls in the beginning of the song "What is beneath the blouse" (Mehta 178)

In effect shots of the actress' heaving breasts and the pelvic jerks of dancers were excised from the final version. Thus in its intense scrutiny of the female body, the censorship and obscenity codes governing Hindi cinema exemplify how the state isolates it as the prime site of control and regulation in the public sphere.

The public outrage and the rhetoric of moral indignation over the unabashed, self reflexive celebration of female sexuality and the female body in the song picturisation found expression in innumerable complaint letters to the Chairman of the Censor Board, many of whom were BJP members such as the President of the BJP Women's Wing who wrote:

Choli ke peechey kya hai is an obscene song and as a result of which new anti-social elements have got the excuse of singing this song on seeing girls. Many incidents of eveteasing have occurred. The film song singers only just to earn money are shamelessly singing such type of songs which are against the public interest. (Mehta 174) 
Another BJP member observed that due to the song being sung by anti-social elements "it had become very difficult for girls and women to go out. In case the above song is going to continue, the next song would be: kachi ke peechey (behind the underwear) and peti cot ke peechey (behind the petticoat)..." (175)

Thus, recurrent opposition "over the perceived proliferation of visual sexual images under globalisation" (John \& Niranjana 581-4) was indicative of a growing anxiety and unease about the emerging visibility of female bodies/sexuality and the predicaments that larger forces of globalisation generated. According to Brinda Bose,

the past decade (1990s) has been enormously significant for censorship in India (xiv)....the BJP had a determined agenda by which it used its state machinery to systematically suppress what it considered 'wrongful' representations of sexuality (among other issues) in the Indian mass media. (xxxix)

It may be said that the Khalnayak controversy triggered what Brinda Bose refers to as a "BJP censor-wave" of films such as Bandit Queen (1994), Kama Sutra (1996), Maachis (Matches, 1996), Char Adhyay (Four Chapters, 1997), Train to Pakistan (1997), Zakhm (Wound, 1998), Godmother (1999) and Gajagamini (2001) suggesting that "the proliferation of 'cases' involving state interventions in censoring sexual representations over the past decade indicates that such an avowed agenda was being relentlessly pursued" (xxxix). However, as the next case study reveals, it wasn't only sexual images that provoked censorship as the fear of communal violence provided yet another pretext for state intervention.

\section{Case Study: Bombay (1995)}

The Censor Board's handling of Mani Ratnam's film Bombay would become a showcase of bad practice as the police, the Chief Minister and the Shiv Sena leader Bal 
Thackeray, "the ex officio Board of Censors" (Gopalan 27) would be asked to act as proxy censors which would set a sinister precedent for future 'mob' censorship ${ }^{15}$ as exemplified by Deepa Mehta's films Fire in 1998 and Water in 2000 which was abandoned before filming commenced due to violence by Hindu vigilantes.

In 1995 the pre-release tensions surrounding Bombay brought to the fore simmering Hindu-Muslim tensions inflamed by the demolition of the mosque, the Babri Masjid ${ }^{16}$ in December 1992 by the Hindu Right. Bombay threatened to open old wounds and insecurities of the Muslim minority that was living in fear of a recurrence of the 1993 communal riots and violence in Bombay, reportedly exacerbated by Thackeray's incendiary hate speeches and a communalised police force. The film, set against the backdrop of these riots, daringly portrayed a love story of a Hindu man and a Muslim woman. It provided sufficient fodder for yet another protracted censorship controversy involving the State, the police and the Shiv Sena, with the Censor Board caught in the interstices of this complex and nebulous power relation. Lalitha Gopalan asserts that

....as with all negotiations between the state and film producers in the 1990s, Bombay too had to contend with the extraordinary powers of the Hindu right in what can only be characterised as the slow erosion of civil society, most evident in the dismantling of the legitimate process of statecraft, which was superseded either by the military and state police forces or by vigilantes. (26)

Fearing the release of Bombay would create law and order problems from the Shiv Sena, the Revising Committee of the Censor Board constituted by its chairman Shakti Samanta (a well-known director of Bengali and Hindi films) previewed the film along with home ministry and crime branch officials. According to two reports in the Indian Express, five topranking police officials were deputed by the Home Ministry to decide if Bombay was fit for 
public consumption. The Bombay city police commissioner "felt the film was not fit for public viewing and that its exhibition involved risk" (Noorani 240). In a clear abdication of the statutory power vested in the Censor Board, Samanta decided to seek the Home Ministry's expert opinion as the film dealt with a sensitive issue. A hard-hitting portrayal of Thackeray ${ }^{17}$ was considered to be too 'strong' by the Censor Board despite the dialogues being a direct lift from his inflammatory speeches about 'ethnic cleansing' in Bombay. A decision remained pending in the interim as the government took its time.

According to Noorani, Samanta's decision to refer to the police as proxy film censors was unconstitutional, contravening a 1989 Supreme Court judgement ${ }^{18}$ that baldly asked the question: "What good is the protection of freedom of expression if the state does not take care to protect it?" thereby making it impermissible to delay, let alone refuse, certification because of the fear of violence. Not only did the Censor Board and the Chairman make a mockery of the law, they violated Section 5 of the Cinematograph Act, 1952 which provides for outside assistance only through advisory panels thus ruling out extra-constitutional or extra-legal assistance. The Act confers discretion on the authorities it sets up and the Censor Board cannot abdicate its duties and functions in favour of others be they the police or the chief minister (240). According to Pendakur, “...by playing it safe bureaucratically and handing over its authority to the Home Ministry and the chief minister of the state, the chairman of the Board abdicated his responsibility to uphold the law" (Indian Popular Cinema 81).

In a placatory telex message to the Information and Broadcasting Ministry the regional officer of Bombay elaborated on the six general cuts leading to a " $U$ " certification ${ }^{19}$ that included deletion of the words 'Pakistan', 'Islamic state' and 'Afghanistan' wherever it occurred; deletion of the visual of all exterior shots of Babri Masjid; the dialogue and visuals of the character based on Thackeray, visuals of paramilitary men firing at a crowd with white 
cap on the ground, implying worshipping Muslims, and, the reduction of violent scenes by $25 \% .{ }^{20}$ Perusing these recommendations, Gopalan writes:

...it is clear that the recommendations tended to protect the police from allegations of partiality and of excessive force, and, in effect, implied that the Muslims' response to the Hindu right for demolishing Babri Masjid had been unwarranted...there is no doubt that the need to place blame or to understand the motivation of the riots now seems more arbitrary than should have been necessary in a narrative film...(26)

To complicate matters further, "Thackeray would play a significant role in the film's postproduction phase, demanding changes and exercising his authority as the head of the powerful Shiv Sena" (23). After a special screening of the film Thackeray expressed his displeasure on seeing his character, played by Tinnu Anand, portrayed as repenting at the violence caused by his party. This scene was excised in the version finally released, the director having submitted to pressures from Thackeray although some of his other demands such as removing a character, re-shooting it with another actor and changing the name to Mumbai were not met. Under the given circumstances, this was a feat since, as Gopalan remarks, "Thackeray is accustomed to having his demands heeded and his every whim entertained. Given his expanding dominion, it is surprising that Ratnam managed to retain the title Bombay" (28).

Submitted for a routine certification on 25 December 1994, Bombay had to clear ten different levels of committee before the Board of Censors passed a ruling and was finally released in Bombay on 15 April 1995 (Gopalan 24, 32). However, despite complying with the cuts ordered by the Censor Board and negotiating with Thackeray the director received death threats and in July 1995 he survived an attempt on his life when his house was bombed (Pendakur "Censorship" 26). Pendakur observes, 
these incidents prove that no matter how many cuts or compromises, the film would be opposed by someone or the other and that the role of the state should be to protect free expression and not to second guess how the viewers would respond or which political party would oppose the film. ("Censorship" 26)

Notably during this period increasing calls for the outright banning of films reached a fever pitch. Such rhetoric called for further governmental policing of cinema. Muslims groups viewed the film as "anti-Islamic," objecting to certain scenes allegedly misrepresenting the religion, and called for the government to first censor, then ban the film. Dissatisfied by the state's response which they feared was partisan towards the Hindus, Muslim leaders ultimately called for the boycott of Bombay (Gopalan 29-32).

Thus, Bombay was ravaged by various competing authorities attempting to re-inscribe itself in its production and reception, a text so excessively worked over and compromised that it resulted in half truths, historical inaccuracies and distortions, a "disingenuous evenhandedness" (Gopalan 36) in locating responsibility for the violence of 1993 and "a gaping hole in the representational regime of the film that conveniently exculpate(d) the police" (Gopalan 35).

The case study provides evidence of the growing politicisation of the censorship process through the 1990s. According to Times of India, "the past decade (1988-1998) has been the decade of intolerant censorship by governments held to ransom by lumpen elements...the lumpensation of Indian democracy has been crowned by censorship by lumpens...successive governments (having) succumbed to mob pressure" (Dhavan). Frequent recourse to manifest and 'mob' censorship revealed the political anxiety of the Hindu Right to influence public opinion whilst attempting to stifle oppositional discourses. "Underlin(ing) how aggressive responses to cinema (were) becoming a routine occurrence," in a strongly- 
worded Times of India article entitled, "Cinema pays the price when government gives in to fringe elements," author and academic, Vrinda Nabar opined, “extra-constitutional interference is becoming a way of life, and violence is increasingly seen as a legitimate way to address issues...whether it is the cinema...(or) anything that is state controlled" (Sekhar and Shedde).

\section{Case Study: War and Peace (2002)}

During the BJP governance from 1999 to mid-2004 the Censor Board unleashed a repressive regime of indiscriminate excision and expurgation of films that included documentary cinema. The extreme politicization of the censorship process is best illustrated by the treatment meted out to Anand Patwardhan, India's most famous documentary filmmaker and well-known for his "courageous, cinematically challenging films about key socio-political issues" (Rajadhyaksha and Willemen, 174), who had been embroiled in a lengthy legal battle over War and Peace (2002), a film that was openly critical of the Hindu Right's jingoistic politics.

At this point I should mention that by including a discussion of War and Peace, I am positioning documentary films alongside commercial Hindi films whilst acutely aware that the circuit of distribution and exhibition for documentary films is very different when compared to popular Hindi films. It is important to emphasise that the history of documentary filmmaking in India has a separate trajectory and the 'public' for documentary films such as War and Peace is imagined (both by filmmakers and state institutions) very differently. ${ }^{21}$ Documentary films have been historically invested with notions of "truth" and "realism" by both the state and Indian audiences. Associations with veracity would often justify more stringent censorship of documentary and non-fiction films by the state compared with the fictional mode of representation of popular Hindi cinema, famous for its dream/fantasy sequences and song and dance picturisations. 
Filmed over a period of three years following the 1998 nuclear tests in India, War and Peace is a three-hour long documentary that explores the rise of Indian jingoism, militarism and the globalisation of the arms trade. It begins with the assassination of Mahatma Gandhi and follows the rise of fundamentalism and the spread of nationalist propaganda. The portrayal of the glaring sense of misplaced patriotism instigated by politicians is striking (Katakam “A Battle Won”).

The struggle with the Censor Board began when the Examining Committee (two out of the four committee members being functionaries of the ruling BJP) recommended six deletions which the director refused to accept. On presenting the film to the Revising Committee, then headed by a former BJP legislator from Gujarat, the deletions were increased to twenty-one cuts, which on appealing to the Film Certification Appellate Tribunal (FCAT) were reduced to two cuts with one addition to be made. The director petitioned the High Court to remove all interventions. Meanwhile in an unprecedented move by the Censor Board, it petitioned the High Court to overrule FCAT's directives and re-impose all the twenty-one cuts (Katakam “A Battle Won”). According to the filmmaker, the cuts demanded by the Censor Board reflected a partisan attitude, driven by a political agenda that took exception to the mildest criticism of the BJP.

The legal wrangle finally came to an end after one and a half years when the Mumbai High Court ordered its release without any cuts or changes since the Censor Board was forced to withdraw a petition that turned out to be baseless. According to the filmmaker, the judges had asked the Censor Board if they had ever in their history appealed against the orders of their own higher authority. When the response was negative the judges then inquired as to what special interest the Censor Board had in the matter of War and Peace that had prompted them to challenge the order of the FCAT. Since no coherent reply was 
forthcoming, the Censor Board at the suggestion of the judges withdrew its petition challenging the order of the FCAT (www.patwardhan.com/writings/press/042403.htm).

The High Court's verdict, mentioned on Patwardhan's website, is significant as it underscores attempts by the Censor Board to infringe upon freedom of speech and expression and to compromise democratic aspirations of the nation. It reads thus:

It is quite possible that the persons in authority today may feel that what they see is the only correct facet of it though it may not be so. It is only in a democratic form of government that the citizens have the right to express themselves fully and fearlessly as to what is their view point... Freedom of speech and expression is important not merely for the consequences that ensue in the absence thereof but since the negation of it runs as an anti-thesis to basic human values, instincts and creativity. It is high time that the persons in authority realize the significance of freedom of speech and expression rather than make and allow such attempts to stifle it. (www.patwardhan.com/writings/press/042403.htm)

The Censor Board had objected to several scenes that allegedly violated its guidelines and if screened would create a law-and-order problem. The cuts were a blatant revelation of the political power that manipulated the Censor Board and therefore warrant closer analysis. Sample cuts were made available to the public in a press release by the filmmaker in 2002 where he mentioned how he discovered that two of the four members of the Examining Committee were functionaries of the ruling party (Patwardhan " 21 Cuts"). Cut One demanded the deletion of the visuals of Mahatma Gandhi being shot by his killer who was a member of the Rashtriya Swayam Sevak (RSS), another right-wing Hindu party whose ideology is shared by the BJP. Cut Two was made on the grounds of violence -- the filmmaker is quick to point out that "a visit to any Bollywood film will 
prove how lax Censor Board (sic) is about gratuitous violence in the entertainment driven commercial cinema" (Patwardhan "21 Cuts").

The Censor Board have repeatedly overlooked the violence in so-called patriotic films such as the 2001 jingoistic film Gadar: Ek Prem Katha (Mutiny: A Love Story) or the 2003 LOC (Line of Control), a film on Indian soldiers fighting during the IndoPakistan war at Kargil. However, quite perversely, the Censor Board tried its level best to prevent a documentary on peace and communal harmony from being screened justifying its concerns on the grounds of law and order. It is ironic that "nuclear weapons (were) believed to prevent war and a film on peace (was) seen as a potential instigator of violence" (Joseph "Censoring peace amid nuclear 'deterrence"”).

Cuts Five, Eight, Seventeen and Eighteen were all deletions of references to the BJP. Cut Nine was a Dalit (low caste) song about the killing of Gandhi by a Brahmin. Cut Sixteen asked for the deletions of visuals of the President of India, who is coincidentally a scientist responsible for India's nuclear development, whilst Cut Twenty one, probably the most shocking in a list of undemocratic cuts, was a general cut asking for the deletion of all visuals and dialogues of all political leaders including the then-President, Prime Minister and Ministers (Nanda "Censorship and Indian Cinema").

In February 2005 War and Peace won the National Award awarded by the same President responsible for the nuclear bomb and whose visuals had been at the centre of controversy. It is important to note here that the BJP-led NDA government had lost the general elections in May 2004, much to the shock of pollsters and political pundits alike. The case study thus illustrates the vulnerability of Indian cinema to State pressures and the distortions that can take place when decisions are based on biased political considerations. As Shammi Nanda asserts, "It was a clear case of the Censor Board acting as an institution of the State to direct public discourse and to safeguard its interests" since "War and Peace 
was critical of India's nuclear bomb which had been projected by the State as a major national achievement...” (“Censorship and Indian Cinema”).

However, it is also important to recognize ongoing efforts, such as the "Campaign Against Censorship" launched by a coalition of three hundred documentary filmmakers in August 2003 (www.freedomfilmsindia.org/aboutus.asp), that have been successful, particularly in recent times with the decline of the right-wing, in mobilizing public opinion against a repressive state censorship regime. Since hegemony is always contested and unstable it is of significance to note that the state's attempts to re-inscribe itself in the process of meaning production and reception have not been total and all-powerful.

\section{Censorship and Cultural Nationalism}

Writing in 2002, Ashish Rajadhyaksha suggests that “the BJP's own investment into the concept of a 'cultural nationalism' (took) the lead in resuscitating the concept of nation from the very real threats that the State face(d) as an institution of legitimation, particularly following its policy of widespread disinvestment in a range of functions" ("The Bollywoodisation of the Indian Cinema” 102). Was censorship in the 1990s then a political instrument wielded to assert the supremacy of State power and governance since it was being challenged by a convergence of external forces such as economic liberalization and foreign capital investment, globalization and the 'invasion' of foreign satellite television? And following from Rajadhyaksha's illuminating work, how can one situate the question of censorship now that the state has reworked its relationship to the film industry post-1998? In the present context, censorship is more relaxed with the proliferation of sexy item numbers and a new trend of erotic films exploring female sexuality in Hindi cinema (as well as in other regional cinemas such as Tamil and Telegu) such as Jism (2003), Khwahish (Desire, 2003) and Murder (2004), with scantily-clad Indian actresses such as Bipasha Basu and Mallika Sherawat, making Choli Ke Peeche seem quite tame in comparison (N.K. Deoshi 
"Bollywood: Sex out of the Closet in 2003"). And communal violence has appeared subsequently in Hindi films to some powerful effect such as in Dev (2004), with its strong implications of just who is fanning the communalist flames. How can one account for this unexpected liberal turn from roughly 2003 onwards?

I would like to propose, by way of a possible answer, that censorship was a fundamental principle of Hindu cultural nationalism which was in gradual decline, postGodhra riots $^{22}$ in 2002. Through the '90s, with the ascendance of the Hindu Right, the Indian nation was re-imagined as Hindu. I argue that this re-invention of the national imaginary through the lens of a militarized Hindu nationalism was based on the broad conceptualisation of censorship as a process of selection of one hegemonic discourse over another. Censorship could thus be understood not only at the cinematic level of cutting and excision but also as a way of reading Hindu nationalist discourse that was predicated on a series of exclusions. This was achieved through the process of censoring the other from the national imagination -- the other often donning various garbs of the Muslim, the sexual female subject, the poor, the rural, the lower caste and even the West according to the Right's political and cultural agenda. As Peter van der Veer points out, "Nationalism is a selective, homogenizing discourse that tends to demarcate social boundaries sharply and to narrow down the diversity and ambiguity of everyday life (105).” This imaginative remapping of India as Hindustan or the land of Hindus led to, what the Nobel Laureate Amartya Sen in his book The Argumentative Indian refers to as, the "miniaturisation" of the nation that was based on a "belligerently sectarian interpretation of Hinduism," severely undermining India's capacious, heterodox past, its celebration of plurality and tolerance (46). 


\section{NOTES}

${ }^{1}$ The Hindu Right is a nationalist, right wing political movement devoted to creating a Hindu state in India. It includes the Bharatiya Janata Party (BJP) (the political arm of the Right which was in power from 1999-2004 and was defeated by the Congress in the 2004 General Elections), the Rashtriya Swayam Sevak (RSS) (the main ideological component of the Right) and the Vishwa Hindu Parishad (VHP). Other parties include the extremist, anti-Muslim regional party Shiv Sena. These organisations collectively promote the ideology of Hindutva -- an ideology that seeks to establish a Hindu state in India. There are several offshoots and newer segments of the Hindu Right, which include the Bajrang Dal (BJD) and women's wings of the main and subsidiary bodies. Together they are the Sangh Parivar or the United Family.

2 This Supreme Court judgement was dated 30-3-1989 in Civil Appeals Nos. 13667-68 of 1988 relating to the censorship of the film "Ore Ore Gramathile" (Tamil).

${ }^{3}$ The underlying logic of the censorship codes reveal that Lee Grieveson's observations on the regulatory concerns about early cinema in America are applicable to the Indian context: the belief that suggestion by way of the moving image would provoke imitative acts of a sexual and/or criminal nature. Since the masses are considered by the State, the elite, and the educated to be impetuous and anti-social, incapable of self-governance and unable to maintain specular distance, cinema, particularly Hindi cinema due to its immense popularity with the "masses", has to be placed in the hands of the State to be controlled by stringent censorship regulations. See Grieveson, Policing Cinema. 
${ }^{4}$ For a detailed account of this Act and its implications on gender, see Section 3 of Brinda Bose, Gender \& Censorship, 99-192.

${ }^{5}$ Hindutva literally translates as "Hinduness," coined by V.D. Savarkar, denoting nationalist, revivalist, chauvinistic Hinduism that forms the basis of Hindu right-wing ideology and the movement for a Hindu nation.

${ }^{6}$ Dharma is a basic tenet of Hinduism meaning a moral and ethical standard of conduct, duties and obligations or the right way of living through which Hindus could achieve salvation or 'nirvana' and escape the cycle of re-birth and reincarnation.

${ }^{7}$ Underworld mafia links to the Hindi film business is supposedly the worst kept secret in Bombay. There are widely varying accounts of the degree to which films are funded by illegal, black money from mafia dons and gangs operating outside the country often from the Middle East. This murky film-mafia nexus comes to the fore whenever there are killings, shootings and/or attempts on the lives of prominent film personalities, directors, producers etc. There have been many legal trials in the recent past that have been dismissed due to inconclusive, insufficient evidence -- often witnesses turning hostile due to death threats and fear of reprisal by the mafia. See Pendakur (2003) Indian Popular Cinema and Arjun Appadurai (2000) "Spectral Housing and Urban Cleansing: Notes on Millennial Mumbai." Public Culture 12(3).

${ }^{8}$ In January 1997 the youth wing of the VHP, the Bajrang Dal attacked an exhibition by the prominent Indian artist M. F. Hussain for having painted goddess Saraswati in the 'nude'. The controversies surrounding Salman Rushdie's book, The Moor's Last Sigh and Arundhati Roy's Booker Prize winning novel The God of Small Things illustrate how the Right defined and controlled the terms of the debate. The former fell foul of the Right as a central character 
resembled the Shiv Sena leader Bal Thackeray; the latter book for having an explicit lovemaking scene between a woman and a lower class man. Magazine covers became increasingly contentious: the most famous example was 'the Anjali Kapur controversy' after an interview with the aforementioned female lawyer who had posed in legal robes and 'seminude' for the cover of Fantasy was published in the November 1994 issue of the reputed India Today magazine. She was accused by the Delhi Bar Association of "professional misconduct" and was threatened with having her license revoked. In May 1997 the cover of Stardust, the national film magazine, featuring a morphed nude photograph of a famous actress Pooja Bhatt caused moral panic. In August 1995 controversy broke out around an advert for Tuff shoes depicting two nude models, lovers in real life, wearing the running shoes whilst embracing each other with a snake wrapped around their bodies. Charges under the Indecent Representation of Women's Act, 1986 were filed against the models leading to the subsequent withdrawal of the ad.

${ }^{9}$ For a detailed account of the role of the Ramayana serial as a key BJP electoral strategy in fuelling Hindu nationalism in the Indian public sphere see Arvind Rajagopal's Politics After Television: Hindu Nationalism and the Reshaping of the Public in India. Cambridge: Cambridge University Press. 2001.

${ }^{10}$ Bania is a pejorative Hindi word for a Hindu trading community originating in the western state of Gujarat.

${ }^{11}$ For an in-depth and engaging analysis of both these cultural controversies articulating competing national(ist) imaginations see "“Gandhi Meet Pepsi’: Nationalism and Electronic Capitalism in Indian Television" and "Nikki Tonight, Gandhi Today: Television, Glocalization, and National Identity" in Shanti Kumar's Gandhi Meets Primetime. 
12 'Public' in the sense that concern was expressed in the name of Indian tradition, public morality and the nation.

${ }^{13}$ In India "eve teasing" is a euphemism for sexual harassment or molestation of women.

14 According to the Central Board of Film Certification (CBFC) website on film classification, the "UA" certificate is defined as "Unrestricted Public Exhibition - But With Parental Guidance."

${ }^{15}$ By 'mob' censorship I refer to instances when a film is forced to be withdrawn from public screenings after being cleared by the Censor Board due to the violence caused by a few fringe elements, usually right-wing that create law and order problems, as in the case of Fire which was released, quite significantly, without any cuts by the Censor Board. The State, usually the Home Ministry, succumbs to such strong-arm tactics by being forced to recall and reconsider censoring the already released film. In the case of Water, this was pre-empted as the film was forced to be abandoned before a single shot had been taken due to mob violence. 500 supporters of Sangh Parivar, the alliance of Hindu fundamentalist organisations associated with the BJP, marched to the Ganges River where they destroyed the set. Among the participants were members of the RSS, VHP, Shiv Sena and the Kashi Sanskriti Raksha Sangharsh Samithi (KSRSS), an amalgam of several Hindu fundamentalist organisations. After wrecking the film set, the mob held a meeting and vowed to stop the film. Police officers made no attempt to arrest any of those responsible. http://www.wsws.org/articles/2000/feb2000/film-f12.shtml (accessed on 15th November 2006). For further details on Fire see Ratna Kapur. "Too Hot to Handle." Feminist Review 64 (Spring, 2000): 53-64 and on Water see Edwina Mason. "The Water Controversy and the Politics of Hindu Nationalism." Hindu Nationalism and Governance. Eds. John McGuire and Ian Copland. New Delhi: Oxford University Press. 2007. 303 - 315. 
${ }^{16}$ The demolition of the Babri Masjid at Ayodhya, supposedly the birthplace of the mythic god Ram, was a rallying point for all Hindu nationalists and the Vishwa Hindu Parishad (VHP) who had launched a movement in 1984, The Ram Janmabhoomi - Babri Masjid for the building of a temple to the mythic god Ram on the site of this mosque. In a dubious rewriting of history by the Hindu Right, it was allegedly the original site of a temple that had been destroyed by a marauding Muslim ruler Babur who invaded the Indian subcontinent in the $16^{\text {th }}$ century. This movement gathered momentum in the $1990 \mathrm{~s}$ and formed an integral part of the BJP/NDA electoral manifesto.

${ }^{17}$ From all accounts it was widely believed that the director Mani Ratnam made a deal with Bal Thackeray to cut a scene lasting nearly four minutes of an incendiary speech by him. See Gopalan.

${ }^{18}$ Supreme Court ruled on March 30, 1989 in S. Rangarajan vs V P Jagjeevan Ram: "If the film is objectionable and cannot constitutionally be restricted under Article 19 (2), freedom of expression cannot be suppressed on account of threat of demonstration and processions or threats of violence... The state cannot plead its inability to handle the hostile audience problem. It is its obligatory duty to present it and protect the freedom of expression." (Noorani 240)

19 According to the Central Board of Film Certification (CBFC) website on film classification, the "U" certification is defined as "Unrestricted Public Exhibition."

${ }^{20}$ Letter from Regional Officer in Bombay, A. Ramakrishnan (RO) to Pradeep Gaur, Desk Officer, Information \& Broadcasting Ministry, [CBFC File No. M/33/95 (part file: Complaint on film Bombay), dated $24^{\text {th }}$ April 1995] 
${ }^{21}$ The State had historically kept documentary filmmaking under tight control through the establishment of the Film Advisory Board (FAB) in 1940, the first instance of direct State production of documentary film in India. Started as part of the Department of Information to advise on the making of propaganda shorts during the Second World War, FAB was intended to collaborate with independent producers/financiers, co-ordinating and overseeing the distribution of indigenous and imported war propaganda films. In 1949, the Films Division (FD) was established, a 'mass - media' unit run by the Ministry of Information \& Broadcasting, it is the central film producing organisation responsible for the production and distribution of newsreels, documentaries and other films required by the Government of India for public information, education and for instructional and cultural purposes. Until the postEmergency period in 1975 , which saw the independently made documentary, the FD had monopoly on documentary cinema in India which were exhibited through compulsory block booking in every permanent cinema in the country. The bulk of the FD's enormous output is by in-house filmmakers. (Rajadhyaksha and Willemen, $95 \& 96$ ).

${ }^{22}$ The Godhra riots refer to the massacre of Muslims in the BJP-administered state of Gujarat in 2002. The extremist right-wing youth group, Bajrang Dal had been accused by the international Human Rights Watch and the Indian Human Rights Commission of direct involvement in the killings (See Sen 52). 


\section{WORKS CITED}

Bharatiya Janata Party. “Our Policy on Media, Cinema, Arts.” BJP Election Manifesto 1998, Chapter 17. Accessed 10th November 2006. <http://www.bjp.org/manifes/chap17.htm>.

"BJP Film Cell Warns of Action," Trade Guide, Bombay. 9 April 1994.

Bose, Brinda, ed. "Introduction." Gender \& Censorship. New Delhi: Women Unlimited, 2006. xiii-xlvi.

Central Board of Film Certification. “Annual Report of 1998.” Ministry of Information \& Broadcasting, Government of India. 1998.

- "Film Censorship: What Everyone Should Know." Ministry of Information \& Broadcasting, Government of India.

"Background: Film Classification." Accessed 30 May

2008. <http://www.cbfcindia.tn.nic.in/backgroundpage3.htm>.

Deoshi, N.K. "Bollywood: Sex out of the Closet in 2003." Accessed 31 May 2008. <http://www.apunkachoice.com/scoop/bollywood/20031226-0.html>.

Dhavan, Rajeev. "Dousing the Fire of Free Expression." The Times of India 9 December 1998. Times Archival System. Bombay, India.

Films For Freedom. Accessed 31 May 2008. <www.freedomfilmsindia.org/aboutus.asp>.

Ghosh, Sohini. "The Troubled Existence of Sex and Sexuality: Feminists Engage with Censorship." Image Journeys: Audio-Visual Media and Cultural Change in India. Eds. Christiane Brosius and Melissa Butcher. New Delhi, London: Sage Publications, 1999. 233260. 
. "Feminists Engage With Censorship." Screen India. 18 July 2003. Accessed

13 November 2005. <http://www.screenindia.com/fullstory.php?content_id=5020>.

Gopalan, Lalitha. Bombay. London: British Film Institute, 2005.

Grieveson, Lee. Policing Cinema: Movies and Censorship in Early-Twentieth Century America. Ewing, NJ, USA: University of California Press, 2004.

--------.- "Cinema Studies and the Conduct of Conduct." Lecture at University of Nottingham, 22 November 2006.

John, Mary. E., and Tejashwini Niranjana. "'Mirror Politics'." Economic and Political Weekly $34.10-11$ (1999): $581-4$.

Joseph, Ammu. “Censoring peace amid nuclear 'deterrence'.” India Together August 2002. Accessed 15 December 2005.

<http://www.indiatogether.org/peace/opinions/censorpeace.htm>.

Katakam, Anupama. “A Battle Won.” World Press Review 50.8 (2003). Accessed 6 October 2005. <http://www.worldpress.org/Asia/1251.cfm>.

Kapur, Ratna. "Who Draws the Line? Contemporary Issues of Speech and Censorship in India." Economic and Political Weekly 31. 16-17. April 20-27 (1996). WS15-WS30.

Kumar, Shanti. Gandhi Meets Primetime: Globalization and Nationalism in Indian Television. Urbana \& Chicago: University of Illinois Press. 2006.

Mehta, Monika. "What Is Behind Film Censorship? The Khalnayak Debates." Gender \& Censorship. Ed. Brinda Bose. New Delhi: Women Unlimited. 2006. 170-187.

Nanda, Shammi. "Censorship and Indian Cinema: The Case of War and Peace." Bright Lights Film Journal 38 Nov. 2002. Accessed 15 December 2005.

<www.brightlightsfilm.com/38/indiacensor.htm>.

Nayar, Sheila J. "Invisible Representation: The Oral Contours of a National Popular Cinema." Film Quarterly 57.3 (2004): 13-23. 
“New Instructions For Film Censorship,” Film Information, Bombay. 17 December 1994.

Noorani, A.G. "Police as Film Censors," Economic and Political Weekly, 4 February (1995): 240.

Oza, Rupal. "Showcasing India: Gender, Geography and Globalization." Signs 26.4 (2001): $1067-1095$.

Patwardhan, Anand. "21 cuts demanded by Censor Board on "War and Peace." First Run Icarus Films 24 August 2002. Accessed 6 October 2005.

<http://www.frif.com/new2002/wandp3.html>. . “Judgement Day.” Accessed 15 May 2008.

<www.patwardhan.com/writings/press/042403.htm>.

Pendakur, Manjunath, “Censorship.” Gender \& Censorship. Ed. Brinda Bose. New Delhi: Women Unlimited. 2006. 19-30.

Indian Popular Cinema: Industry, Ideology and Consciousness.

Cresskill, N.J: Hampton Press. 2003.

Prasad, Madhava. Ideology of the Hindi Film: A Historical Construction. New Delhi: Oxford UP. 1998.

Rajadhyaksha, Ashish. “The Bollywoodisation' of the Indian Cinema: Cultural Nationalism in a Global Arena." City Flicks: Cinema, Urban Worlds and Modernities in India and Beyond. Ed. Preben Kaarsholm. International Development Studies: Roskilde University. 2002. 93-111.

and Paul Willemen. Encyclopaedia of Indian Cinema. London: British

Film Institute. 1999.

Sekhar, Vaishnavi, and Meenakshi Shedde. "Cinema Pays the Price when Government Gives Into Fringe Elements.” The Times of India 13 July 2001. Times Archival System. Bombay, India. 
Sen, Amartya. The Argumentative Indian: Writings on Indian History, Culture and Identity.

London: Allen Lane. 2005.

van der Veer, Peter. Religious Nationalism: Hindus and Muslims in India. Berkeley and Los

Angeles: University of California Press. 1994.

Vasudev, Aruna. Liberty and License in the Indian Cinema. New Delhi: Vikas Publishing

House. 1976.

Vasudevan, Ravi. “National Pasts and Futures: Indian Cinema.” Screen 41.1 (2000): 120. 